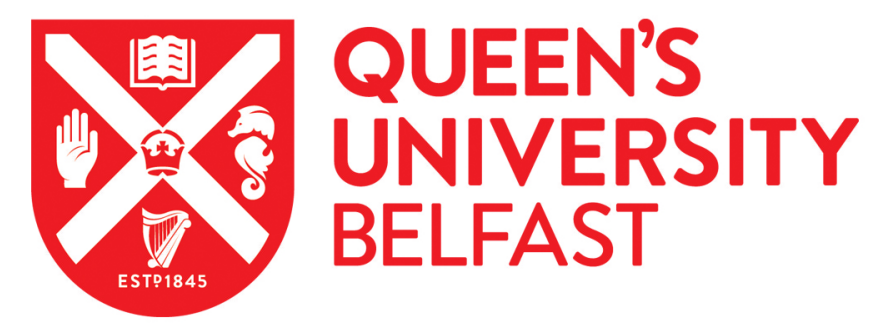

\title{
Bulk tissue and amino acid stable isotope analyses reveal global ontogenetic patterns in ocean sunfish trophic ecology and habitat use
}

Phillips, N. D., Elliott Smith, E. A., Newsome, S. D., Houghton, J. D. R., Carson, C. D., Alfaro-Shigueto, J., Mangel, J. C., Eagling, L. E., Kubicek, L., \& Harrod, C. (2020). Bulk tissue and amino acid stable isotope analyses reveal global ontogenetic patterns in ocean sunfish trophic ecology and habitat use. Marine Ecology Progress Series, 633, 127-140. https://doi.org/10.3354/meps13166

Published in:

Marine Ecology Progress Series

Document Version:

Peer reviewed version

Queen's University Belfast - Research Portal:

Link to publication record in Queen's University Belfast Research Portal

Publisher rights

Copyright 2020 Inter Research. This work is made available online in accordance with the publisher's policies. Please refer to any applicable terms of use of the publisher.

\section{General rights}

Copyright for the publications made accessible via the Queen's University Belfast Research Portal is retained by the author(s) and / or other copyright owners and it is a condition of accessing these publications that users recognise and abide by the legal requirements associated with these rights.

Take down policy

The Research Portal is Queen's institutional repository that provides access to Queen's research output. Every effort has been made to ensure that content in the Research Portal does not infringe any person's rights, or applicable UK laws. If you discover content in the Research Portal that you believe breaches copyright or violates any law, please contact openaccess@qub.ac.uk. 
1 Bulk tissue and amino acid stable isotope analysis reveal global ontogenetic patterns in ocean sunfish trophic ecology and habitat-use

N.D. Phillips*1,2, E.A. Elliott Smith*3, S.D. Newsome ${ }^{\# 3}$, J.D.R. Houghton ${ }^{1,2}$, C.D. Carson ${ }^{4}$, J.

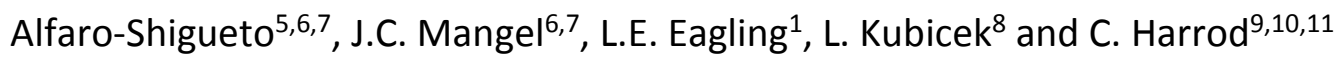

5

$6{ }^{1}$ Queen's Marine Laboratory, 12-13 The Strand, Portaferry, BT22 1PF; ${ }^{2}$ School of Biological

7 Sciences, 19 Chlorine Gardens, Belfast, BT9 5DL

8

${ }^{3}$ Department of Biology, The University of New Mexico, Albuquerque, NM 87131, U.S.A.

9

${ }^{4}$ The New England Coastal Wildlife Alliance, 11 Clarence Soule Drive, Middleboro, MA 02346

${ }^{5}$ Universidad Cientifica del Sur, Facultad de Biologia Marina, Ant Panamericana Sur km 19,

11 VES, Lima and ${ }^{6}$ ProDelphinus, Jose Galvez 780E, Lima 15074, Peru; ${ }^{7}$ Centre for Ecology and

12 Conservation, College of Life and Environmental Sciences, University of Exeter, Penryn

13 Campus, Penryn, Cornwall, TR10 9EF, UK

${ }^{8}$ Aussermattweg 22, 3532, Zäziwil, Switzerland

${ }^{9}$ Instituto de Ciencias Naturales Alexander von Humboldt, Universidad de Antofagasta,

Avenida Angamos 601, Antofagasta, Chile; ${ }^{10}$ Instituto Antofagasta, Universidad de

Antofagasta, Avenida Angamos 601, Antofagasta, Chile; ${ }^{11}$ Núcleo Milenio INVASAL,

18 Concepción, Chile

19

*Denotes joint first authors 
$1 \quad$ \#Author to whom correspondence should be addressed: Natasha Phillips;

2 nphillips01@qub.ac.uk

3 Running head: Global patterns in sunfish trophic ontogeny

\section{Abstract}

6

Ocean sunfish (Mola spp.) have largely been considered as obligate gelativores, however

7 recent research has suggested that they undergo an unusual life history shift. In this study analyses of bulk and amino acid nitrogen $\left(\delta^{15} \mathrm{~N}\right)$ and carbon $\left(\delta^{13} \mathrm{C}\right)$ stable isotope ratios were employed to provide detailed insight into ontogenetic variation in sunfish trophic ecology and habitat-use and to assess whether any observed patterns were common to populations around the world. Through this combined approach, a clear ontogenetic shift was identified in both trophic ecology and habitat-use of ocean sunfish indicating a complex trophic role that changes from more benthic to pelagic-derived prey on a continuous scale as fish grow larger. The data also revealed strong population structuring with potential to assess connectivity between distinct groupings using isotopic analysis. When combined, these new insights into sunfish ecology may be of value to conservation management teams, indicating a broad ecological role, distinct population clustering and possible transAtlantic movements. These results suggest that the current mass bycatch of ocean sunfish may have far-reaching ecological implications and further highlights the growing need for conservation management of this vulnerable genus. 
1 Keywords: diet, pelagic, benthic, energy pathways, ontogeny, Mola, bycatch, trophic

2 position

\section{Introduction}

5 Anthropogenic pressures have reportedly reduced the biomass of marine megafaunal

6 predators by $90 \%$ over the last 50 years (Myers \& Worm 2003, McCauley et al. 2015),

7 resulting in pronounced ecological impacts (Cox et al. 2002, Heithaus et al. 2008). Ecosystem

8 studies examining the longer-term consequences of such mass removal of large fishes,

9 however, are currently limited by a paucity of data regarding the complexity of marine food

10 webs and the top-down role of consumers (Cox et al. 2002, Myers et al. 2007, Heithaus et al.

11 2008). In light of these growing concerns, here we provide new insights into the trophic

12 ecology of ocean sunfish (Genus Mola), a vulnerable group (Jing et al. 2015) subject to

13 intensive bycatch globally (Petersen \& McDonell 2007, Mangel et al. 2018, Nyegaard et al.

2018). This group is not a primary target for global fisheries, (although smaller markets do

occur across Asia), they are of low commercial value and remain unprotected by management regulations (Jing et al., 2015). However, as global fisheries effort increases, scientists and conservation bodies have noted an alarming rise in the bycatch of these fishes (Silvani et al. 1999, Cartamil \& Lowe 2004, Petersen \& McDonell 2007, Nyegaard et al. 2018), highlighting a pressing need to understand the potential consequences of removing significant numbers from marine systems. Unwanted capture of sunfish is now estimated to remove hundreds of thousands of individuals across the global ocean each year (see review, Pope et al. 2010) and has resulted in the International Union for Conservation of Nature (IUCN) classifying ocean sunfish as 'Vulnerable' to extinction globally, but 'Data Deficient' on 
1 regional scales (Jing et al., 2015). This study was conceived to address some of these

2 knowledge gaps to aid the conservation and management of this vulnerable taxa.

3 Ocean sunfish are unusual fish: they can grow to $\sim 3 \mathrm{~m}$ in length and weigh $\sim 2.3$ tonnes

4 (Roach 2003). Smaller individuals form large schools in nearshore waters, then become

5 more solitary and move into pelagic environments as they grow (Silvani et al. 1999, Cartamil

6 \& Lowe 2004, Pope et al. 2010). Alongside their large body size, ocean sunfish are notable

7 for their somewhat unusual ecological niche, with a diet largely (putatively) composed of

8 gelatinous zooplankton (e.g. Fraser-Brunner 1951; MacGinitie \& MacGinitie 1968; Hooper et

9 al. 1973). Recent research has shown that the gelatinous portion of the sunfish diet extends beyond typical jellyfishes (scyphozoans), incorporating a wide range of gelatinous taxa including pyrosomes, siphononphores, salps and ctenophores (e.g. Potter and Howell 2011;

12 Cardona et al. 2012; Nakamura et al. 2015; Thys et al. 2015). Although research over the last 50 years (and in more recent times, the popular media) has largely focused on their role as putative obligate gelativores (MacGinitie \& MacGinitie 1968, Hooper et al. 1973), it is increasingly clear that smaller sunfish consume a more diverse diet (e.g. Fraser-Brunner 1951) containing both pelagic and benthic prey, with a shift towards a more gelatinous diet as they grow (e.g. Syväranta et al. 2012; Nakamura \& Sato 2014; Sousa et al. 2016). coastal food webs, with stomach contents noted to contain algae, crustaceans, ophiuroids, molluscs, hydroids and fish, alongside gelatinous prey (e.g. Norman \& Fraser 1949; FraserBrunner 1951; Clemens \& Wilby 1961). More recent studies based on stable isotope analysis (SIA) of bulk tissues (i.e. muscle or skin) in both the Mediterranean Sea ( $n=8$, size range: $<100 \mathrm{~cm})$ and the NW Pacific $(\mathrm{n}=17$, size range: $50<200 \mathrm{~cm})$ show that sunfish have higher nitrogen isotope $\left(\delta^{15} \mathrm{~N}\right)$ values by $\sim 6 \%$ relative to gelatinous prey (Syväranta et al. 2012, 
1 Harrod et al. 2013, Nakamura \& Sato 2014), a difference too large to be explained by a

2 single trophic step. Furthermore, smaller sunfish $<1 \mathrm{~m}$ in total length are notably ${ }^{13} \mathrm{C}$ -

3 enriched relative to pelagic taxa (and putative prey) indicating they are likely feeding more

4 in benthic and inshore food webs (Jennings et al. 1997), and have $\delta^{15} \mathrm{~N}$ and $\delta{ }^{13} \mathrm{C}$ values

5 statistically indistinguishable from local benthic-feeding fish species. Overall, these patterns

6 suggest that sunfish are not obligate gelativores (Syväranta et al. 2012, Harrod et al. 2013).

7 However, it is not yet possible to confirm if such prey selection (and potential dietary shifts)

8 can be applied to sunfish populations globally, as sample sizes and comparison between

9 populations in different regions remains limited. Additional data are required to explore the trophic position of sunfish throughout ontogeny to understand their changing ecosystem role. Without such information, there is a high risk that large schools of sunfish in coastal waters will continue to be removed en masse as bycatch, with little understanding of the potential consequences to ecosystem functioning.

In this study, we use both bulk tissue (skin) and amino acid $\delta{ }^{15} \mathrm{~N}$ and $\delta{ }^{13} \mathrm{C}$ stable isotope analysis (SIA) to explore size-related shifts in diet and habitat-use and to consider whether such patterns are ubiquitous among sunfish populations around the globe. The use of bulk tissue SIA in trophic ecology is largely based on the concept of predictable isotopic differences between consumers and their prey (Vanderklift \& Ponsard 2003; Peterson \& Fry 2008). $\delta^{15} \mathrm{~N}$ values have been used extensively to estimate consumer trophic level, since they typically increase by $\sim 2-5 \%$ o per trophic step due to preferential excretion of ${ }^{14} \mathrm{~N}$ in nitrogenous waste products (e.g. ammonia) synthesized by consumers (DeNiro \& Epstein 1981, Pinnegar \& Polunin 1999, Vander Zanden \& Rasmussen 2001). In contrast, $\delta{ }^{13} \mathrm{C}$ values vary less between trophic levels ( 0-2\%o), and instead typically vary between different functional groups of primary producers and thus provide a means to identify use of habitats 
1 fuelled by different sources of production (France 1995, Perry et al. 1999), e.g. pelagic

2 versus benthic (which can vary by $\sim 5-10 \%$, with benthic endmembers having higher $\delta^{13} \mathrm{C}$

3 values than pelagic sources). By combining these approaches and assessing the $\delta^{13} \mathrm{C}$ and

$4 \quad \delta^{15} \mathrm{~N}$ values of consumer tissues, it becomes possible to simultaneously characterise habitat-

5 use and dietary strategy.

Although SIA of bulk tissues collected from marine consumers can be highly informative, it must be noted that the (baseline) isotopic composition of primary producers can vary both spatially and temporally (Graham et al. 2010). Potential differences in localised baselines makes comparisons between differing populations challenging and often means isotopic values cannot be interpreted without corresponding baseline values, which requires a priori understanding of species ecology. Recently, $\delta^{13} \mathrm{C}$ and $\delta^{15} \mathrm{~N}$ analysis of individual amino acids has been used to tease apart the relative influence of variation in baseline isotope values from variation in diet composition and trophic level (e.g. Bowes \& Thorp 2015). For $\delta^{13} \mathrm{C}$ analysis, amino acids are divided into traditional 'essential' and 'nonessential' groups. Although plants, algae (Protoctista), fungi, and bacteria can synthesize essential amino acids ( $A A_{E S S}$ ) de novo, animals typically cannot and are only able to obtain these from their diet (e.g. Hare et al. 1991; O’Brien et al. 2002; Fogel 2003). Some animals have demonstrated symbiosis with the gut microbiome (Newsome et al. 2011), when hosts consume a protein-deficient diet.

Consequently, the $\delta^{13} \mathrm{C}$ values of $\mathrm{AA}_{\mathrm{ESS}}$ generally show no significant isotopic discrimination between diet and consumer (the minimal isotopic alteration between diet and consumer), and thus can identify the primary source(s) of production at the base of the local food web (Howland et al. 2003, Larsen et al. 2013, McMahon et al. 2015, Elliott Smith et al. 2018). Furthermore, patterns in amino acid $\delta^{13} \mathrm{C}$ values can change in response to biosynthetic 
1 pathways and mode of carbon acquisition, which are different among plants, protists, fungi,

2 and bacteria (Scott et al. 2006, Larsen et al. 2009, 2013), which is likely because these

3 synthesizers utilise unique biosynthetic pathways to synthesize $A A_{E S S}$ that imprints on their

$4 \quad \delta^{13} \mathrm{C}$ composition (Larsen et al. 2009, 2013). These unique $A A_{E S S} \delta^{13} C$ 'fingerprints' are

5 potentially of great value to trace the ultimate source of primary production that

6 contributes to the diet of consumers that occupy any trophic level of the food chain.

7 For $\delta^{15} \mathrm{~N}$, amino acids are commonly grouped into 'source' and 'trophic' forms, a

8 classification based on the relative degree of isotopic discrimination with trophic transfer.

9 Source amino acids undergo minimal isotopic discrimination between trophic levels, because metabolic processing of these forms does not lead to deamination of the amine group, and thus there is minimal potential for ${ }^{15} \mathrm{~N}$ isotopic fractionation (Popp et al. 2007, McMahon et al. 2015, O'Connell 2017). Thus, source amino acids can provide a measure of the $\delta^{15} \mathrm{~N}$ composition of the base of the food web(s) in which consumers forage.

Alternatively, trophic amino acids are heavily involved in nitrogen metabolism and undergo significant isotopic discrimination with increasing trophic level. Thus, comparison of $\delta^{15} \mathrm{~N}$ values among source and trophic amino acids can provide a relative measure of a consumer's trophic position (e.g. Popp et al. 2007; McMahon 2015; McMahon et al. 2015). This approach permits the estimation of baseline isotopic composition and trophic position from a single consumer tissue sample without the need for extensive sampling of basal sources of production (e.g. Chikaraishi et al. 2009), providing a powerful tool for simultaneously studying the diet and movements of elusive marine consumers (McMahon et al. 2015 .

As isotope-based approaches often use non-lethal sampling methods to unravel the trophic ecology and habitat-use of wide-ranging consumers, such data have the potential to 
1 provide novel insights into the ecological role of ocean sunfish across their global range,

2 without requiring the sacrifice of individual fish (as has been noted in previous dietary work

3 pers. coms. 2019). In light of current fisheries pressures, including unregulated target

4 fisheries and mass bycatch, (e.g. Silvani et al. 1999; Cartamil \& Lowe 2004; Petersen \&

5 McDonell 2007; Nyegaard et al. 2018), such insights are sorely needed. For this study, our

6 goal was to use isotope data to examine sunfish trophic ecology. Firstly, we used bulk tissue

7 SIA and mixing models to quantify prey taxa in the diet of sunfish throughout ontogeny at a

8 regional scale within the Mediterranean Sea. Secondly, we extended our analysis of the

9 Mediterranean sunfish population with $\mathrm{AA}_{\mathrm{ESS}} \delta^{13} \mathrm{C}$ fingerprinting to assess pelagic versus

benthic contributions to diet. Thirdly, we looked for global patterns in sunfish trophic

ecology by comparing bulk tissue SIA, AA $\delta{ }^{13} \mathrm{C}$ fingerprinting and $\mathrm{AA} \delta{ }^{15} \mathrm{~N}$-derived trophic

level estimates derived from samples collected from around the world. By providing a better understanding of the diet, trophic level, and habitat use of ocean sunfish, our aim is to gain new data for species management and to facilitate prediction of the potential ecological consequences if the mass removal of sunfish continues.

\section{Materials and Methods}

2.1 Sample Collection. Samples of ocean sunfish tissues (genus Mola) were collected from multiple sites across their global range (see Table 1; Supplementary Materials), including the Mediterranean Sea, the North East and North West Atlantic, the North East and South East Pacific. All sampled fish were morphologically identified as Mola mola, however without genetic analyses to confirm species identification, for the purposes of this study we refer to our samples at genus level. The primary sampling site for this study occurred in the northern Mediterranean off the north-west Italian coast, where there is a predictable annual bycatch 
1 of ocean sunfish in the Camogli tuna fishery or tonnarella (Cappanera 2016). Regular

2 sampling of bycatch at this site occurred during the summer fishing period (May-July) in 2015 and 2016, enabling collection of a large dataset.

During sampling, fish were maintained in the deep tuna nets or in a tethered keep-net until processing on a large tarpaulin on deck. The tuna nets were emptied three times daily and so it is not believed that the natural diet of the sunfish was affected by the brief period where they were held captive in the nets. Furthermore, by sampling tissues that turnover over a longer time frame than the captive setting, even if the sunfish were able to access non-typical food sources this should not be reflected in the data (Newsome et al. 2010, Madigan et al. 2012). Following consultations with the veterinary team at Queen's University Belfast, all sampling was carried out with the approval and support of the Portofino Area Marina Protetta and in accordance with Queen's University ethical guidelines. Processing time was kept to a minimum (2-7 minutes), where each specimen was measured for total length (TL: $\pm 1 \mathrm{~mm}$ ) and mass ( $\pm 1 \mathrm{~g}$ ) before a selection of tissues were sampled, after which fish were released. No mortalities occurred during processing and each fish was observed to swim away or dive upon release; although subsequent possible capture-related affects or mortalities are not known. The samples collected for SIA consisted of a tissue punch from the dorsal flank of the fish behind the fin $(2 \mathrm{~mm}$ in diameter) including skin and subcutaneous capsule material (Davenport et al. 2018).

\section{Background samples of representative taxa of local putative prey and primary producers} were collected by snorkel surveys from several locations along the Ligurian coastline (with permission from the Area Marine Protteta di Portofino authorities), purchased from local markets or donated from unwanted discards by local fishermen; see Table 1 and Appendix 1 for additional details. Additional samples of stranded or bycaught ocean sunfish from other 
locations were collected opportunistically or donated by colleagues (Table 1; Supplementary Materials). All samples were dried at $60^{\circ} \mathrm{C}$ for 12 hours upon collection and later frozen for storage or frozen directly and shipped to the University of New Mexico Center for Stable Isotopes (UNM-CSI, Albuquerque, NM USA) for subsequent processing and stable isotope analysis.

2.2 Bulk Tissue $\delta^{13} \mathrm{C}$ and $\delta^{15} \mathrm{~N}$ Analysis. Once in the laboratory, a sub-set of sunfish skin samples were selected for analysis of carbon $\left(\delta^{13} \mathrm{C}\right)$ and nitrogen $\left(\delta^{15} \mathrm{~N}\right)$ stable isotope ratios to provide the broadest size range possible from each location sampled. This included 22 fish from Italy $(40<97 \mathrm{~cm} \mathrm{TL})$, six from NE USA $(107<215 \mathrm{~cm} \mathrm{TL})$, four from Peru, $(39<94$ $\mathrm{cm} \mathrm{TL})$, two from the UK (72<76 cm TL) and two from NW USA (each $41 \mathrm{~cm} \mathrm{TL})$. Since the majority of our sunfish samples were collected from Italy, locally collected background samples from the Italian site were also analysed for $\delta^{13} \mathrm{C}$ and $\delta^{15} \mathrm{~N}(\mathrm{n}=59)$, to characterise the local ecosystem and consider putative prey (see Appendix 1).

For bulk tissue $\delta^{13} \mathrm{C}$ and $\delta^{15} \mathrm{~N}$ analysis, putative prey items were dissected, homogenized, and subsampled; Mola tissue samples were lyophilized and subsampled. Prey and Mola tissue samples were not lipid-extracted for bulk tissue isotope analysis as mass percent $[\mathrm{C}] /[\mathrm{N}]$ data indicated that samples contained little lipids (average $[\mathrm{C}] /[\mathrm{N}]=3.2$ for Mola skin tissue). Approximately $0.5-0.6 \mathrm{mg}$ of prey and Mola samples, and $\sim 5 \mathrm{mg}$ of macroalgae samples were weighed into tin capsules. Carbon $\left(\delta^{13} \mathrm{C}\right)$ and nitrogen $\left(\delta^{15} \mathrm{~N}\right)$ isotope values, along with mass percent $[\mathrm{C}]$ and $[\mathrm{N}]$ (as a quality control metric for our protein samples), were measured via EA-IRMS using a Costech 4010 elemental analyser (Costech, Valencia, CA) coupled to a Thermo Scientific Delta V Plus isotope ratio mass spectrometer (Thermo Fisher Scientific, Bremmen, Germany) at the UNM-CSI. The within- 
1 run standard deviation of multiple organic reference materials was $\leq 0.2 \%$ of for both $\delta^{13} \mathrm{C}$ 2 and $\delta^{15} \mathrm{~N}$ values.

3 Following bulk tissue analysis, selected sunfish skin samples $(n=36)$ were analysed for

$4 \quad A_{E S S} \delta^{13} C$ and a subset of these $(n=12)$ were selected (across our measured size range: $41<$ $5215 \mathrm{~cm} \mathrm{TL}$ ) for $\mathrm{AA} \delta^{15} \mathrm{~N}$ analyses. For both $\mathrm{AA} \delta^{13} \mathrm{C}$ and $\delta^{15} \mathrm{~N}$ analysis, $\sim 7 \mathrm{mg}$ of each Mola sample was hydrolysed to its constituent amino acids in $1 \mathrm{~mL}$ of $6 \mathrm{~N}$ hydrochloric acid $(\mathrm{HCl})$ at $110^{\circ} \mathrm{C}$ for 20 hours in tubes flushed with $\mathrm{N}_{2}$ to prevent oxidation during hydrolysis. $\mathrm{A}$ selection of background primary producer samples from the Mediterranean Sea sites $(n=8$, including representative green macroalgae and phytoplankton samples, see Table 1 Supplementary Materials) were also hydrolysed in $1 \mathrm{~mL}$ of $6 \mathrm{~N} \mathrm{HCL}$, with the exception of whole silica filters containing POM which were hydrolysed with $1.5 \mathrm{~mL}$ of $6 \mathrm{~N} \mathrm{HCl}$. Hydrolysed producer samples were passed through a cation exchange resin column (Dowex 50WX8 100-200 mesh) to isolate amino acids from other metabolites and filter silicates (for POM only) from our producer samples (Amelung \& Zhang 2001). After hydrolysis/Dowex purification, amino acids were derivatised to $\mathrm{N}$ - trifluoroacetic acid isopropyl esters following established protocols (O'Brien et al. 2002, Newsome et al. 2011, 2014). Samples were derivatised in batches of 8-17 along with a house-made reference material containing all amino acids for which we obtained $\delta^{13} \mathrm{C}$ and $\delta^{15} \mathrm{~N}$ values from our samples.

$\delta^{13} \mathrm{C}$ and $\delta^{15} \mathrm{~N}$ values of derivatised amino acids were measured using a GC-C-IRMS system. Derivatised samples were injected into a $60 \mathrm{~m} \mathrm{BPx5}$ gas chromatograph column for amino acid separation (0.32 ID, $1.0 \mu \mathrm{m}$ film thickness, SGE Analytical Science, Victoria, Australia) in a Thermo Scientific Trace 1300, combusted into $\mathrm{CO}_{2}$ gas via a Thermo Scientific GC Isolink II, and analysed with a Thermo Scientific Delta V Plus isotope ratio mass spectrometer at UNMCSI. Samples were run in duplicate and bracketed with our internal 
1 amino acid standard. For $\delta^{13} \mathrm{C}$ analysis, samples were rerun if any $A A_{E S S}$ exhibited standard

2 deviations $>0.7 \%$ across injections. For the analytically more challenging $\delta^{15} \mathrm{~N}$ analysis, we

3 set this threshold to $1.0 \%$. The within-run standard deviations of measured $\delta^{13} \mathrm{C}$ values among $A A_{E S S}$ in the reference material ranged from $0.1 \%$ (Leucine) to $2.1 \%$ (Glycine). The

5 within-run standard deviations of measured $\delta^{15} \mathrm{~N}$ values among $A A_{E S S}$ in the reference material ranged from $0.2 \%$ (Serine) to $1.2 \%$ (Glutamic Acid).

We reliably measured $\mathrm{AA} \delta^{13} \mathrm{C}$ and $\delta^{15} \mathrm{~N}$ values of eleven amino acids: alanine (Ala), aspartic acid (Asp), glutamic acid (Glu), glycine (Gly), serine (Ser), isoleucine (Ile), leucine

9 (Leu), lysine (Lys), phenylalanine (Phe), threonine (Thr) and valine (Val). Of these, we used the essential amino acids Ile, Leu, Lys, Phe, Thr and Val for amino acid fingerprinting (as we can assume minimal isotopic alteration through trophic levels), and for amino acid $\delta^{15} \mathrm{~N}$ based estimates of trophic level we used data for Phe (source) and Glu (trophic). The reagents used during derivatisation add carbon to the side chains of amino acids, and hence raw $\delta^{13} \mathrm{C}$ values measured via GC-C-IRMS reflect a combination of the intrinsic amino acid carbon and reagent carbon (Silfer et al. 1991); see Data S1 for correction equations. AA $\delta^{15} \mathrm{~N}$ reflects only intrinsic molecular nitrogen, and for these analyses we corrected samples within each run using known $\delta^{15} \mathrm{~N}$ values of our internal amino acid standard. All data are available in the Supplementary Materials (Table 1).

2.3 Data Analysis. Isotope data were plotted with ggplot2 (Wickham 2009), a coding package within $R$ ( $R$ version 3.2.2 Development Core Team 2008). Bulk tissue stable isotope values were used to 1) compare Mola values relative to putative prey and local fish species (Fig. 1), 2) assess isotopic patterns against Mola size (Fig. 2a and b), and 3) estimate consumption of different prey through mixing models (Fig. 3; Stock and Semmens 2013). 
$1 \quad$ Putative prey were selected using published gut content analyses (e.g. Fraser-Brunner 1951;

2 Sousa et al. 2016) and arranged a priori into five functional groups: pelagic zooplankton,

3 benthic grazers, benthic scavengers, sessile filter feeders and pelagic fisheries discards; sources within each functional group exhibited equality of means (T-tests, $p<0.05)$. Once

5 data were pooled and the mean isotope values and associated standard deviations were

6 calculated, we used SIAR (Stable Isotope Analysis in R) (Parnell et al., 2008) to fit a Bayesian

7 model to estimate the relative contribution of putative prey sources to sunfish diet. Mean $( \pm$

$8 \mathrm{SD}$ ) trophic discrimination factors (TDFs) were estimated as $2.0 \pm 1.3 \%$ ofor $\delta^{13} \mathrm{C}$ and $3.0 \pm$

$9 \quad 1.2 \%$ for $\delta^{15} \mathrm{~N}$ based on fish muscle values published by McCutchan et al. (2003) and used by Syväranta et al. (2012) and Harrod et al. (2013). The models were then run following the methods of Inger et al. (2013). Models were run for sunfish grouped into three size classes $(<0.5 \mathrm{~m}, 0.5<0.75 \mathrm{~m}$ and $>0.75 \mathrm{~m} \mathrm{TL})$ to consider potential ontogenetic changes in dietary contributions.

Linear discriminatory analyses (LDA) were used to classify sunfish samples collected globally by comparing their $\mathrm{AA}_{\mathrm{ESS}} \delta^{13} \mathrm{C}$ values to potential carbon sources (clustered into bacteria, macroalgae and microalgae groups). We selected primary producer and bacteria data from the dataset provided in Larsen et al. (2013), which included representative macroalgae (genera: Cystoseira, Laminaria, Macrocystis, Pelvetiopsis, Petrospongium, Ralfsia, Scytosiphon, Silvetia, Calliarthon, Corallina, Endocladia, Mastocarpus and Odonthalia) and pelagic microalgae (genera: Adhnanthes, Emiliana, Isochyrsis, Prasinocladus and Stauroneis). Additional primary producer samples collected from sites near Camogli, Italy were added to the producer dataset, including filtered microalgae and macroalgae from the genera Ulva and Dictyota. The final primary producer $\mathrm{AA}_{\mathrm{ESS}} \delta^{13} \mathrm{C}$ data were used as a training dataset with cross validation reporting $84 \%$ classification success. Sunfish were 
1 then included in the LDA to be classified with potential producers; we assumed no $\delta^{13} \mathrm{C}$

2 trophic discrimination for essential AAs. The LDA was first run to identify the producer

3 groups associated with the Mediterranean sunfish (Fig. 4a), and then using the same parameters we ran the global sunfish dataset to consider whether similar patterns were

5 observed across broader geographic scales (Fig. 4b).

We used AAs $\delta^{15} \mathrm{~N}$ values to estimate the relative trophic position of Mola. Since species-specific amino acid $\delta^{15} \mathrm{~N}$ trophic discrimination factors are not available for sunfish, here we estimated relative trophic position using $\delta^{15} \mathrm{~N}$ data for the canonical trophic AA Glu minus that of the source AA Phe. This calculation considers geographical variation in isotopic baselines to provide a relative measure of sunfish trophic position with larger Glu-Phe $\delta^{15} \mathrm{~N}$ offsets indicative of feeding at a higher trophic level.

\section{Results}

The Mediterranean ocean sunfish dataset provided the greatest size range of fish from a single location in this study, and as such these data were used to consider our first two aims: 1) to unravel the trophic role of ocean sunfish and 2) to explore the potential for ecological ontogenetic shifts. To consider the trophic ecology of Mediterranean sunfish relative to the local ecosystem, their bulk $\delta^{13} \mathrm{C}$ and $\delta^{15} \mathrm{~N}$ isotopic values (corrected for trophic discrimination) were plotted alongside the mean values of locally caught coastal species and offshore catches (from depths $<1000 \mathrm{~m}$ ) that were discarded in nearshore waters (Fig. 1).

Overall, it was apparent that $\delta{ }^{13} \mathrm{C}$ and $\delta{ }^{15} \mathrm{~N}$ values differed between taxa, with ${ }^{13} \mathrm{C}$-depleted (mostly pelagic species) and ${ }^{13} \mathrm{C}$-enriched (mostly benthic species) spread across ${ }^{15} \mathrm{~N}$ enriched (higher trophic position) and ${ }^{15} \mathrm{~N}$-depleted (lower trophic position) spaces. Individual sunfish $\delta^{13} \mathrm{C}$ and $\delta^{15} \mathrm{~N}$ values extended across these broad groups, with the bulk 
1 of sunfish samples appearing substantially ${ }^{13} \mathrm{C}$ and ${ }^{15} \mathrm{~N}$-enriched beyond their putative

2 gelatinous prey (although this excludes a small cluster of larger-bodied individuals which

3 were more associated with gelatinous zooplankton).

4 When sunfish bulk $\delta{ }^{13} \mathrm{C}$ and $\delta{ }^{15} \mathrm{~N}$ values were considered relative to total body length (TL;

$5 \mathrm{~cm}$ ), the results indicated a strong ontogenetic shift, which was apparent between the $20 \mathrm{~cm}$

6 TL size increments. Although individual variation occurs, these data suggest there is a

7 significant decline in $\delta^{13} \mathrm{C}\left(\mathrm{R}^{2}=0.67, \mathrm{P}<0.0001\right)$ and $\delta{ }^{15} \mathrm{~N}\left(\mathrm{R}^{2}=0.80, \mathrm{P}<0.0001\right)$ values ontogenetically by $\sim-3 \%$ and $\sim-2.5 \%$ o respectively, between body sizes of $\sim 40 \mathrm{~cm}$ and $\sim 90$ $\mathrm{cm}$. To visualise isotopic variability against fish length as a continuum, both $\delta^{13} \mathrm{C}$ and $\delta^{15} \mathrm{~N}$ values were then plotted against individual TL (Figs. 2a and b). These figures reveal considerable individual variation, but with a strong overall decline in both $\delta{ }^{13} \mathrm{C}$ and $\delta{ }^{15} \mathrm{~N}$ with TL.

Mixing models were then employed to estimate the contribution of different prey groups for Mediterranean sunfish ontogenetically, with individuals grouped into three size classes $(<50$ $\mathrm{cm}, 50>75 \mathrm{~cm}$ and $>75 \mathrm{~cm} \mathrm{TL}$; see Table 1 and Fig. 3). These results suggested that smaller sunfish $(<50 \mathrm{~cm} \mathrm{TL})$ fed predominately on benthic taxa which formed $\sim 57 \%$ of prey for this life stage (modal values; 28\% benthic grazers and 29\% sessile filter feeders). Although the majority of prey items were benthic in origin, the diet of smaller sunfish was also supplemented by a significant proportion of pelagic gelatinous zooplankton which formed $\sim 27 \%$ of prey. As sunfish increased in size, mixing models indicated that their diet incorporated increasingly more gelatinous prey, from $\sim 27 \%$ to $~ 72 \%$ over the size range noted here, however it must be noted that even the largest Mediterranean individuals appear to supplement their gelatinous prey intake with other prey taxa. 
1 To consider potential ontogenetic shifts in sunfish carbon sources, the Mediterranean

2 sunfish $A A_{E S S} \delta{ }^{13} \mathrm{C}$ samples were run in a linear discriminatory analysis with fish grouped

3 into $20 \mathrm{~cm}$ size classes (Fig. 4a) alongside a broad producer dataset. The resulting LDA suggested that the Mola $\mathrm{AA}_{\mathrm{ESS}} \delta^{13} \mathrm{C}$ fingerprint most closely classified with microalgae,

5 however it was noted that smaller individuals had a significant association with macroalgae

6 (representing approximately a third of all carbon sourced by fish $<40 \mathrm{~cm}$ ), with a shift

7 towards microalgae as fish total length increased. This evidence supports our proposed

8 dietary shift from more benthic to pelagic prey with increasing body size. For data tables of

$9 \quad$ LDA classifications, please see Supplementary Materials Table 2a.

To extend our analyses beyond a single population and consider sunfish isotopic patterns on a broader scale (the third aim of this study), bulk values of $\delta^{13} \mathrm{C}$ and $\delta{ }^{15} \mathrm{~N}$ were plotted from sunfish samples collected around the world (Fig. 5). The results indicated broad patterns of population clustering between Mediterranean, Atlantic and Pacific Ocean basins. Within these strong groupings, we noted that Pacific specimens sampled from Peru and the west coast of the USA clustered together, whereas samples collected from the east coast of the USA clustered with one collected from England. Aside from these groupings, there were a couple of notable outliers, including one specimen from the east coast of the USA with a significantly lower $\delta{ }^{15} \mathrm{~N}$ value $\left(\delta^{13} \mathrm{C}-17.3 \%\right.$ o, $\delta^{15} \mathrm{~N} 9.9 \%$ ), that was more closely associated with the Mediterranean fish. Also noted as an outlier was a sunfish sampled from Northern Ireland that was most closely grouped with samples from the Pacific. The bulk SIA values from each region have a relatively broad range, particularly of $\delta^{13} \mathrm{C}$, and in the Mediterranean data at least, we are confident this represents a shift in diet and habitat-use within the population (range of isotopic values for each location: Mediterranean $\delta^{13} \mathrm{C}-19.7$ 
$1<-17.0 \%, \delta{ }^{15} \mathrm{~N}-9.1<-6.6 \%$; Atlantic $\delta^{13} \mathrm{C}-18.6<-15.1 \%, \delta^{15} \mathrm{~N}-12.6<-9.8 \%$; Pacific $\delta{ }^{13} \mathrm{C}-$

$2 \quad 20.9<-17.7 \%, \delta^{15} \mathrm{~N}-13.6<-11.3 \%$ ).

3 To consider the potential sources of primary production for sunfish over such broad scales, the global sunfish samples $\mathrm{AA}_{\mathrm{ESS}} \delta{ }^{13} \mathrm{C}$ were then run in a linear discriminatory

5 analysis (Fig. 4b) with our collated producer dataset (Larsen et al. 2013 data and our Italian producers). The results suggested that most sunfish classified with microalgae sources (data

7 tables detailing LDA classifications are shown in Supplementary Materials Table 2b).

8 However, the data also suggest a small proportion of smaller-bodied individuals use

9 macroalgae carbon sources, an input that significantly declines with increasing body size.

Given the distribution of data relative to the putative energy sources, there may also be a

missing source producer that has not yet been identified, or more variation between producer values than illustrated by this dataset. The AA $\delta{ }^{15} \mathrm{~N}$ dataset provided further insight into the trophic position of sunfish at a global level (Fig. 6) through the comparison of AA $\delta^{15} \mathrm{~N}$ of trophic (glutamic acid) and source amino acids (phenylalanine). The difference between these values (having removed local baseline effects), varied substantially (Fig. 6), indicating that smaller sunfish $(<1 \mathrm{~m} \mathrm{TL})$ had variable trophic positions, in contrast to our

17 limited sample size of larger individuals with lower, and less variable Glu-Phe values, indicating a lower (and less variable) trophic position.

\section{Discussion}

Our data provide novel insight into the complex ecology of ocean sunfish, with bulk tissue

SIA and mixing models revealing evidence of a continuous ontogenetic shift from benthic to pelagic prey in the Mediterranean Sea. By extending this investigation using analysis of $A A_{E S S}$ $\delta{ }^{13} \mathrm{C}$ 'fingerprints', and trophic-source AA $\delta^{15} \mathrm{~N}$ offsets, we were able to assess the baseline 
carbon contributions to diet in this population, and then consider the potential for such ecological patterns on a global scale. Given the current fisheries pressures on Mola, these data are highly valuable to understand their diet and habitat use, providing baseline information for conservation management and the inclusion of this widespread predator in ecosystem models.

\subsection{Mediterranean Sunfish Bulk Tissue $\delta^{13} \mathrm{C}$ and $\delta^{15} \mathrm{~N}$.}

Our data revealed significant declines in Mediterranean sunfish $\delta^{13} \mathrm{C}$ and $\delta^{15} \mathrm{~N}$ values as fish increased in size (Fig. 2). This was consistent with recent work proposing that sunfish show ontogenetic dietary and habitat shifts (Syväranta et al. 2012, Nakamura \& Sato 2014, Sousa et al. 2016). Smaller individuals are suggested to target a mixed diet in nearshore waters before becoming increasingly dependent on gelatinous pelagic prey as body size increases (Nakamura \& Sato 2014, Sousa et al. 2016). While previous studies have noted such a shift may occur between sunfish grouped into broad size classes (e.g. Nakamura and Sato 2014), by incorporating smaller specimens, our results suggested significant shifts in $\delta^{13} \mathrm{C}$ and $\delta{ }^{15} \mathrm{~N}$ values occur over a continuous scale, indicating a gradual dietary change to more pelagic prey (Fig. 2). Previous work in Japan proposed that dietary shifts occurred once a given size threshold was reached (suggested to be $\sim 1 \mathrm{~m} \mathrm{TL}$ ), however, our data suggest that on a broader scale, the picture may be more nuanced. Although our data are collected from smaller fish, the results demonstrate a strong, gradual dietary shift rather than a significant change when a critical body size or other ecological threshold is attained. Although it is apparent that significant variability occurs (Figure 2), possibly reflecting individual diet specialisation, the overall pattern from our bulk isotope data strongly indicated a gradual ontogenetic shift in diet and habitat in this population. 
The suggestion of a continuous dietary shift from the bulk isotope data was further

2

supported by isotope mixing model results, which indicated a gradual decreasing reliance on benthic prey, shifting towards greater proportions of gelatinous zooplankton with increasing body size (Fig. 3). Our results suggested that benthic grazers, filter feeders and fisheries discards are present in the diet of all size classes. The presence of benthic grazers (snails and limpets) alongside sessile filter feeders (mussels and oysters) may represent opportunistic feeding on naturally occurring molluscs, however, it is also possible that Mola sampled in the northern Mediterranean were consuming bivalves from local mariculture facilities, where rope-grown mussels are easily accessible in the water column. Our mixing model results indicated that fishery discards may also make a small contribution to assimilated diet, representing up to $5 \%$ of diet throughout ontogeny. Since many fishes scavenge on discards (e.g. Votier et al. 2010), it is perhaps unsurprising that sunfish, particularly those of smaller sizes which naturally target benthic prey, could opportunistically feed on fisheries waste, however this finding provides the first tentative evidence of scavenging in this taxon. Nevertheless, the limitations of our isotope-based approach must also be considered as mixing models will assign an estimated percentage contribution to all potential sources included in the models, therefore it is possible that the contribution of discards ( $5 \%$ ) or benthic scavengers ( $\sim \%$ ) proposed in the diet may have been exacerbated by model performance. While the relative importance of gelatinous prey (representing $\sim 27-72 \%$ of diet in our sampled fish) is apparent in the mixing model results, the zooplankton species analysed here are by no means a complete evaluation of all taxa available in the Mediterranean. However, by including the dominate scyphozoan, Pelagia noctiluca, alongside a seasonal surge of hydrozoan Velella velella, we have incorporated typical prey 
and those opportunistically consumed under bloom conditions (Arai 2005, Hoving \& Haddock 2017, Phillips et al. 2017).

3

4.2 Sunfish Essential Amino Acid $\delta^{13} \mathrm{C}$ Values. To expand our understanding of the potential

5 basal sources of carbon that contribute to the diet of Mediterranean sunfish, we conducted AA $A_{E S S} \delta{ }^{13} \mathrm{C}$ fingerprinting analyses using an LDA with a global producer dataset (Larsen et al. 2013), alongside samples of local producers (Fig 4a). Given the observed patterns in bulk tissue SIA data, we expected to see evidence of a shift from benthic (e.g. macroalgae) to more pelagic (e.g. microalgae) derived carbon across ontogeny. Our AAESS $\delta^{13} \mathrm{C}$ data demonstrated a strong shift from mixed carbon sources (macro and microalgae) to microalgae alone, with macroalgae featuring only in the diets of the smallest size classes ( $\delta{ }^{13} \mathrm{C}$ source $\sim 30 \%$ macroalgae: $~ 70 \%$ microalgae for fish $\sim 20 \mathrm{~cm}$ TL, shifting to $\sim 1 \%$ macroalgae: $91 \%$ microalgae for fish $\sim 100 \mathrm{~cm} \mathrm{TL}$ ). However, the data also provided strong support for utilisation of microalgae-derived carbon throughout ontogeny. We suggest that this discrepancy was likely driven by utilisation of prey fuelled by benthic (sessile) microalgae, which were expected to have relatively higher bulk tissue $\delta{ }^{13} \mathrm{C}$ values, but similar $\mathrm{AA}_{\mathrm{ESS}} \delta{ }^{13} \mathrm{C}$ fingerprints as pelagic microalgae (phytoplankton). The potential contribution of benthic microalgae to ocean sunfish may be driven by the relatively deep euphotic depth in the Mediterranean Sea (50 < 200 m; Ferrari 2000; Marty et al. 2002; Mignot et al. 2011). It is worth noting that production of benthic microalgae can be high, contributing $\sim 31 \%$ of total microalgal production in the Baltic Sea (Ask et al. 2016) and $~ 25 \%$ in the Mediterranean Sea (Riaux-Gobin et al. 1998), overall providing a substantial contribution to total primary production, particularly in coastal regions (Riera et al. 1996, Cahoon 1999, Glud et al. 2002, Yokoyama \& Ishihi 2003, Ask et al. 2016). This finding 
1 highlights the importance of using a combination of bulk tissue and amino acid isotope data

2 from a wide range of functional groups to characterise habitat use by consumers in local

3 food webs. Further sampling and analysis of both bulk tissue and amino acid isotope values

$4 \quad$ will be required to assess whether microalgal sources can be differentiated into

5 benthic/pelagic groupings and then used to determine localised carbon sources for sunfish

6 in this region. It is also worth noting that there are some sunfish in the LDA not associated

7 with any primary producer group, which may indicate that our $\mathrm{AA}_{\mathrm{ESS}} \delta{ }^{13} \mathrm{C}$ dataset is missing

8 a local carbon source. To fully investigate the carbon sources for sunfish ontogenetically, we

9 suggest collecting a broader database of locally collected producers for a more complete examination of benthic and pelagic carbon sources (Elliot Smith et al., 2018).

Following this assessment of the potential carbon sources for Mediterranean sunfish, we then pooled our $\mathrm{AA}_{\mathrm{ESS}} \delta{ }^{13} \mathrm{C}$ samples collected from across the world, to consider patterns in basal carbon utilisation on a global scale (Fig. 4b). These LDA data again highlighted the role of microalgae-derived carbon in fuelling the resources sunfish consume throughout ontogeny, with a small, declining classification with macroalgae as TL increased (from $\sim 3 \%$ to $0 \%$ as fish TL increased from $\sim 50$ to $250 \mathrm{~cm}$ ). It appeared that macroalgaederived carbon was only utilised by the smallest individuals ( $20 \mathrm{~cm} \mathrm{TL}$ ), and we suggest that the benthic microalgae pathway may also be important here. Further studies should seek to distinguish this from pelagic microalgae carbon sources, e.g. if $\mathrm{AA}_{\mathrm{ESS}} \delta^{13} \mathrm{C}$ values differ between benthic and pelagic microalgae (Vane et al. 2018). Assessing additional isotopes, such as bulk $\delta^{34} S$ may also help to detangle benthic and pelagic sources in future studies (Hobson 1999). Such further work would provide vital new insight, to establish if $A_{\text {ESS }} \delta^{13} \mathrm{C}$ data alone can be used to differentiate between benthic and pelagic sources and then to confirm if benthic microalgae are making important contributions to local ecosystems. 
$24.3 \mathrm{Global}$ Patterns in Sunfish Bulk Tissue $\delta{ }^{13} \mathrm{C}$ and $\delta{ }^{15} \mathrm{~N}$ Values. Despite the need for

3 further clarity on microalgae sources, the bulk SIA and mixing model results enabled us to answer the primary aims of this study. Firstly, that the trophic role of sunfish appears more

5 varied than previously recognised, with evidence of highly opportunistic feeding and scavenging, particularly amongst smaller size classes. Secondly, we found evidence of a strong, continuous ontogenetic shift in our Mediterranean sunfish dataset, with smaller sunfish likely functioning as part of the subtidal benthic food web, slowly incorporating more pelagic, gelatinous prey as body size increases.

Our third aim was to identify patterns in sunfish trophic role on a global scale, which we assessed via bulk tissue $\delta{ }^{13} \mathrm{C}$ and $\delta{ }^{15} \mathrm{~N}$ values, as well as amino acid $\delta{ }^{15} \mathrm{~N}$ analysis of sunfish collected in different ocean basins (Figs. 5 and 6). These data provided new insight into sunfish ecology, revealing significant variation in baseline values between oceans, as noted in similar studies comparing differing oceanic water masses (St John Glew et al. 2019). Our results suggest that bulk tissue isotope values can identify population structuring of sunfish and have the potential to assess individual long-distance movements. Outside of the distinct regional groupings, a few individuals were noted to have isotope values that appear as outliers, which may represent recent migrants which have not yet reached isotopic equilibrium with local isotopic baselines. For example, the outlier specimen with relatively low carbon and nitrogen isotope values that was sampled off the coast of New England, USA $\left(\delta{ }^{13} \mathrm{C}:-17.3, \delta{ }^{15} \mathrm{~N}\right.$ : 9.9) likely travelled from an area with low baseline $\delta^{15} \mathrm{~N}$ values such as the Mediterranean, eastern Atlantic, or Sargasso Sea (it has been suggested that sunfish spawn in the Sargasso Sea (Shapiro EOL webpage; pers. coms.)). In a similar vein, the outlier specimen sampled off the coast of Cornwall, England $\left(\delta^{13} \mathrm{C}:-16.2, \delta^{15} \mathrm{~N}: 12.6\right)$ that clustered 
1 with samples collected in New England, USA may have made the opposite journey, isotope

2 values of this specimen place it well outside of the existing isoscapes of the capture region in

3 the northeast Atlantic (St John Glew et al. 2019). However, further detailed study of sunfish

4 movements would be required to fully explore this concept.

5 The isotopic differences shown by these 'outlier' sunfish are notably similar to those of

6 migratory Mediterranean and North Atlantic fin whale (Balaenoptera physalus) populations,

7 which have been successfully tracked across oceans using SIA (Giménez et al. 2013). The

8 potential for such movements will remain speculative pending further detailed analysis of

9 individual ranges via satellite telemetry and population structuring via genetic analysis to explore the potential for sunfish to undertake trans-Atlantic crossings and attempts to locate potential spawning grounds. Even without precise information on fish movements, however, the new insights into sunfish distribution patterns provided by our results are of great interest, as the potential for isotopic data to identify population structure (Harrod et al. 2005) and long-distance movements is highly significant for stock management (Hoffman 2016). In light of the current mass bycatch of sunfish around the world, this finding may facilitate identification of discreet stocks and prediction of fisheries bycatch impacts, alongside the potential for the replenishment of depleted populations by external migrants. This is of particular importance given the recent recognition that the systematics of fishes in the genus Mola is far more complicated than previously recognised (Nyegaard et al. 2017, Sawai et al. 2017). As such, it is likely that a combination of genetic and isotopic research will be required to classify populations into their respective species and identify individual stocks (Nyegaard et al. 2017, Sawai et al. 2017). 
14.4 Sunfish Amino Acid $\delta^{15} \mathrm{~N}$ Values. We used the $\delta^{15} \mathrm{~N}$ of individuals' AAs to estimate

2 relative trophic position of ocean sunfish globally. Since precise $\delta^{15} \mathrm{~N}$ trophic discrimination

3 factors for specific trophic AAs are unavailable for sunfish, we calculated the difference

$4 \quad\left(\Delta^{15} \mathrm{~N}\right)$ in the $\delta^{15} \mathrm{~N}$ values of the canonical trophic (Glu) and source (Phe) amino acids to

5 estimate relative trophic level (Fig. 6). This enabled direct comparison of each fish's trophic

6 amino acid value minus local baselines, which likely vary significantly as suggested by our

7 global bulk tissue dataset. The results indicated that individual smaller ocean sunfish may

8 occupy a range of trophic levels, perhaps due to differing localised availability of prey taxa

9 or higher competition for resources in coastal environments that drives diversification of

10 individual diet. $\Delta^{15} \mathrm{~N}_{\text {Glu-Phe }}$ values generally decline with increasing body size, suggesting that

11 the trophic position of larger sunfish $(>100 \mathrm{~cm} \mathrm{TL})$ is lower than the average trophic level of smaller individuals (Fig. 6). Interestingly, smaller individuals $(<100 \mathrm{~cm} T L)$ appear to have more trophic plasticity than larger ones. Overall, these patterns suggest that smaller fish have a more diverse diet relative to larger fish and the trophic niche width of sunfish decreases ontogenetically as they specialise on pelagic gelatinous prey as they grow. This interpretation is supported by the bulk isotope data from the Mediterranean sunfish,

17 illustrating a strong, continuous ontogenetic shift in diet (Fig. 2) with the proportion of gelatinous zooplankton prey increasing from $27 \%$ to $72 \%$ as fish grow from $<50 \mathrm{~cm}$ to $>75$ $\mathrm{cm}$ total length. Since the sunfish for this study were sampled across different ocean basins, they are likely to feed on differing local species, but the data suggest they may operate at similar functional levels as indicated by similar $\Delta^{15} \mathrm{~N}_{\text {Glu-Phe, }}$ narrowing their trophic niche as they grow. 
14.5 Conclusions. We identified a clear, continuous ontogenetic shift in the diet and habitat

2 use of Mediterranean ocean sunfish, with the possibility of trophic niche narrowing with

3 increasing fish size. These data confirmed that ocean sunfish are not obligate gelativores

4 throughout their life history, but have a complex trophic role with differing feeding modes

5 ontogenetically. The primary producer data indicated an intriguing relationship between ocean sunfish size and carbon source in the Mediterranean Sea, and here we recommend

7 further research to consider additional local producers and if possible, to differentiate

8 between benthic and pelagic microalgae using $\mathrm{AA}_{\mathrm{ESS}} \delta{ }^{13} \mathrm{C}$ fingerprinting. Such research

9 would enable us to confirm the basal carbon sources used by sunfish and other taxa throughout ontogeny and over broader spatial scales.

This study has also highlighted the potential for SIA to identify individual sunfish movements, which may be of considerable use to assess population structure and connectivity. Since ocean sunfish are subject to unregulated target fisheries and high bycatch globally that removes 100,000 s of individuals per year, our data are important by providing evidence of population structure at the basin scale, potential trans-Atlantic movements, and a broader trophic role than previously recognised. When combined, these elements suggest there may be broad ecological consequences if the mass removal of this genus continues, highlighting an urgent need for active conservation management.

\section{Acknowledgements}

The authors would like to acknowledge the vital supportive role of the Portofino Marine Protected Area Authorities and the numerous days at sea enabled by the fishermen of the Camogli Tonnarella for data collection. We are also very grateful to all the persons who donated sunfish tissues to this study and to the Fisheries Society of the British Isles for 
1 funding the studentship of Natasha Phillips. Additional funding for fieldwork and isotopic

2 analysis was provided by: The Marine Institute, the Flying Sharks Foundation, the Emily

3 Sarah Montgomery travel scholarship and Sir Thomas Dixon travel fellowship through

4 Queen's University Belfast, the Alice McCosh Foundation, the Society of Experimental

5 Ecology and the Royal Society of Biology. $\mathrm{CH}$ is supported by Nucleo Milenio INVASAL,

6 funded by Chile's government programme, Iniciativa Cientifica Milenio from the Ministerio

7 de Economia, Fomento y Turismo. We are also very grateful for the support of Laura

8 Burkemper and Viorel Atudorei from UNM-CSI.

\section{Compliance with Ethical Standards}

10 Conflict of Interest: The Authors declare that they have no conflicts of interest.

11 Ethical approval: All applicable international, national and institutional guidelines for the 12 care and use of animals were followed.

\section{References}

Amelung W, Zhang X (2001) Determination of amino acid enantiomers in soils. Soil Biol Biochem 33:553-562.

Arai MN (2005) Predation on pelagic coelenterates: A review. J Mar Biol Assoc United Kingdom 85:523-536.

Ask J, Rowe O, Brugel S, Strömgren M, Byström P, Andersson A (2016) Importance of coastal primary production in the northern Baltic Sea. Ambio 45:635-648.

Bowes RE, Thorp JH (2015) Consequences of employing amino acid vs. bulk-tissue, stable isotope analysis: A laboratory trophic position experiment. Ecosphere 6. an Annu Rev 37:47-86. 
1 Cappanera V (2016) La Tonnarella. https://www.ziguele.it/tonnarella-di-camogli/

2 Cardona L, de Quevedo IÁ, Borrell A, Aguilar A (2012) Massive consumption of gelatinous

3 plankton by mediterranean apex predators. PLoS One 7.

4 Cartamil DP, Lowe CG (2004) Diel movement patterns of ocean sunfish Mola mola off

5 southern California. Mar Ecol Prog Ser 266:245-253.

6 Chikaraishi Y, Ogawa NO, Kashiyama Y, Takano Y, Suga H, Tomitani A, Miyashita H, Kitazato

$7 \quad H$, Ohkouchi N (2009) Determination of aquatic food-web structure based on compound-specific nitrogen isotopic composition of amino acids. Limnol Oceanogr

9 Methods 7:740-750.

Clemens WA, Wilby A (1961) Fishes of the Pacific coast of Canada. Fish Res Board Canada Bull 68:443.

Cox S, Essington T, KitchelL J, Martell S, Walters C, Boggs C, Kaplan I (2002) Reconstructing ecosystem dynamics in the central Pacific Ocean, 1952-1998. Can J Fish Aquat Sci 59:1736-1747.

Davenport J, Phillips ND, Cotter E, Eagling LE, Houghton JDR (2018) The locomotor system of the ocean sunfish Mola mola (L.): role of gelatinous exoskeleton, horizontal septum, muscles and tendons. J Anat 223:347-357.

DeNiro MJ, Epstein S (1981) Influence of diet on the distribution of nitrogen isotopes in animals. Geochim Cosmochim Acta 45:341-351.

Elliott Smith EA, Harrod C, Newsome S (2018) The importance of kelp to an intertidal ecosystem varies by trophic level : insights from amino acid d13C analysis. Ecosphere 9:p.e02516.

Ferrari GM (2000) The relationship between chromophoric dissolved organic matter and dissolved organic carbon in the European atlantic coastal area and in the West 
Fogel M (2003) Extending the limits of paleodietary studies of humans with compound specific carbon isotope analysis of amino acids. J Archaeol Sci 30:535-545.

France RL (1995) Carbon-13 enrichment in benthic compared to planktonic algae: foodweb implications. Mar Ecol Prog Ser 124:307-312.

Fraser-Brunner A (1951) The ocean sunfishes (Family Molidae). Bull Br Museum (Natural Hist 1:87-121.

Giménez J, Gómez-Campos E, Borrell A, Cardona L, Aguilar A (2013) Isotopic evidence of limited exchange between Mediterranean and eastern North Atlantic fin whales. Rapid Commun Mass Spectrom 27:1801-6.

Glud RN, Kühl M, Wenzhöfer F, Rysgaard S (2002) Benthic diatoms of a high Arctic fjord (Young Sound, NE Greenland): Importance for ecosystem primary production. Mar Ecol Prog Ser 238:15-29.

Hare PE, Fogel ML, Stafford Jr. TW, Mitchell AD, Hoering TC, Stafford TW, Mitchell AD, Hoering TC (1991) The isotopic composition of carbon and nitrogen in individual amino acids isolated from modern and fossil proteins. J Archaeol Sci 18:277-292.

Harrod C, Grey J, McCarthy TK, Morrissey M (2005) Stable isotope analyses provide new insights into ecological plasticity in a mixohaline population of European eel. Oecologia 144:673-683.

Harrod C, Syväranta J, Kubicek L, Cappanera V, Houghton JDR (2013) Reply to Logan \& Dodge: 'Stable isotopes challenge the perception of ocean sunfish Mola mola as obligate jellyfish predators'. J Fish Biol 82:10-6.

Hart JL (1973) Pacific fishes of Canada. Fish Res Board Canada Bull 180:1-740.

Heithaus MR, Frid A, Wirsing AJ, Worm B (2008) Predicting ecological consequences of 
marine top predator declines. Trends Ecol Evol 23:202-210.

Hobson KA (1999) Tracing origins and migration of wildlife using stable isotopes: a review. Oecologia 120:314-326.

Hoffman J (2016) Tracing the Origins, Migrations, and Other Movements of Fishes Using Stable Isotopes. In: An Introduction to Fish Migration. Morais P, Daverat F (eds) CRC Press, p 169-196

Hooper SN, Paradis M, Ackman RG (1973) Distribution of trans 6 hexa decenoic acid 7 methyl 7 hexa decenoic acid and common fatty acids in lipids of the ocean sunfish. Lipids 8:509-516.

Hoving HJT, Haddock SHD (2017) The giant deep-sea octopus Haliphron atlanticus forages on gelatinous fauna. Sci Rep 7:44952.

Howland MR, Corr LT, Young SMM, Jones V, Jim S, Merwe NJ, Mitchell AD, Evershed RP (2003) Expression of the Dietary Isotope Signal in the Compound-specific $813 C$ Values of Pig Bone Lipids and Amino Acids. Int J Osteoarchaeol 65:54-65.

Inger R, Jackson A, Parnell A, Bearhop S (2013) SIAR V4 ( Stable Isotope Analysis in R ) An Ecologist 's Guide. Matrix 4:1-14.

Jennings S, Reñones O, Morales-Nin B, Polunin NVC, Moranta J, Coll J (1997) Spatial variation in the $15 \mathrm{~N}$ and $13 \mathrm{C}$ stable isotope composition of plants, invertebrates and fishes on Mediterranean reefs: Implications for the study of trophic pathways. Mar Ecol Prog Ser 146:109-116.

Jing, L., Zapfe, G., Shao, K.-T., Leis, J.L., Matsuura, K., Hardy, G., Liu, M., Robertson, R. \& Tyler J (2015) IUCN Red list of threatened species. www.iucnredlist.org (accessed 1 January 2016)

Larsen T, Taylor DL, Leigh MB, Brien DMO, Larsen T, Taylor DL, Leigh MB, Brien DMO (2009) 

Stable isotope fingerprinting : a novel method for identifying plant , fungal , or bacterial origins of amino acids. Ecol Soc Am 90:3526-3535.

Larsen T, Ventura M, Andersen N, O’Brien DM, Piatkowski U, McCarthy MD (2013) Tracing Carbon Sources through Aquatic and Terrestrial Food Webs Using Amino Acid Stable Isotope Fingerprinting.

MacGinitie G, MacGinitie N (1968) Natural history of marine animals, 2nd edn. McGraw-Hill

Madigan DJ, Litvin SY, Popp BN, Carlisle AB, Farwell CJ, Block BA (2012) Tissue turnover rates isotope-analysis/ 
1 McMahon KW, Fogel ML, Elsdon TS, Thorrold SR (2010) Carbon isotope fractionation of

2 amino acids in fish muscle reflects biosynthesis and isotopic routing from dietary protein. J Anim Ecol 79:1132-1141.

McMahon KW, Hamady LL, Thorrold SR (2013) Ocean ecogeochemistry: a review. Oceanogr Mar Biol An Annu Rev 51:327-374.

McMahon KW, Polito MJ, Abel S, Mccarthy MD, Thorrold SR (2015) Carbon and nitrogen isotope fractionation of amino acids in an avian marine predator, the gentoo penguin (Pygoscelis papua). Ecol Evol 5:1278-1290.

Mcmahon KW, Thorrold SR, Elsdon TS, Mccarthy MD (2015) Trophic discrimination of nitrogen stable isotopes in amino acids varies with diet quality in a marine fish. Limnol Oceanogr 60:1076-1087.

Mignot A, Claustre H, D’Ortenzio F, Xing X, Poteau A, Ras J (2011) From the shape of the vertical profile of in vivo fluorescence to Chlorophyll-a concentration. Biogeosciences 8:2391-2406.

Myers RA, Baum JK, Shepherd TD, Powers SP, Peterson CH (2007) Cascading effects of the loss of predatory sharks from a coastal ocean. Science (80- ):1846-1850.

Myers RA, Worm B (2003) Rapid worldwide depletion of predatory fish communities. Nature 423:280-283.

Nakamura I, Goto Y, Sato K (2015) Ocean sunfish rewarm at the surface after deep excursions to forage for siphonophores. J Anim Ecol 84:590-603.

Nakamura I, Sato K (2014) Ontogenetic shift in foraging habit of ocean sunfish Mola mola from dietary and behavioral studies. Mar Biol 161:1263-1273.

Newsome SD, Clementz MT, Koch PL (2010) Using stable isotope biogeochemistry to study marine mammal ecology. Mar Mammal Sci 26:509-572. 
1 Newsome SD, Fogel ML, Kelly L, Del Rio CM (2011) Contributions of direct incorporation

2 from diet and microbial amino acids to protein synthesis in Nile tilapia. Funct Ecol 25:1051-1062.

Newsome SD, Wolf N, Peters J, Fogel ML (2014) Amino acid $\delta 13 C$ analysis shows flexibility in the routing of dietary protein and lipids to the tissue of an omnivore. Integr Comp Biol 54:890-902.

Nielsen JM, Popp BN, Winder M (2015) Meta- analysis of amino acid stable nitrogen isotope ratios for estimating trophic position in marine organisms. Oecologia.

Norman JR, Fraser FC (1949) Field book of giant fishes. Putnam GP (ed) New York.

Nyegaard M, Loneragan N, Hall S, Andrew J, Sawai E, Nyegaard M (2018) Giant jelly eaters on the line: species distribution and bycatch of three dominant sunfishes in the Southwest Pacific. Estuar Coast Shelf Sci 207:1-15.

Nyegaard M, Sawai E, Gemmell N, Gillum J, Loneragan NR, Yamanoue Y, Stewart AL (2017) Hiding in broad daylight: molecular and morphological data reveal a new ocean sunfish species (Tetraodontiformes: Molidae) that has eluded recognition. Zool J Linn Soc $182: 1-28$

O’Brien DM, Fogel ML, Boggs CL (2002) Renewable and nonrenewable resources: amino acid turnover and allocation to reproduction in Lepidoptera. Proc Natl Acad Sci U S A 99:4413-4418.

O'Connell TC (2017) 'Trophic' and 'source' amino acids in trophic estimation: a likely metabolic explanation. Oecologia 184:317-326.

Parnell A, Inger R, Bearhop S J AL (2008) SIAR: Stable Isotope Analysis in R

Perry RI, Thompson PA, Mackas DL, Harrison PJ, Yelland DR (1999) Stable carbon isotopes as pelagic food web tracers in adjacent shelf and slope regions off British Columbia, 
Petersen S, McDonell Z (2007) A bycatch assessment of the Cape horse mackerel Trachurus trachurus capensis mid- water trawl fishery off South Africa. Birdlife/WWF Responsible Fish Program Rep 2002-2005.

Peterson, Bruce; Fry B (2008) Stable Isotopes in Ecosystem Studies. Annu Rev Ecol Syst $18: 293-320$.

Phillips N, Eagling L, Harrod C, Reid N, Cappanera V, Houghton J (2017) Quacks snack on smacks: mallard ducks (Anas platyrhynchos) observed feeding on hydrozoans (Velella velella). Plankt Benthos Res 12:143-144.

Pinnegar JK, Polunin NVC (1999) Differential fractionation of $\delta 13 C$ and $\delta 15 N$ among fish tissues: Implications for the study of trophic interactions. Funct Ecol 13:225-231.

Pope EC, Hays GC, Thys TM, Doyle TK, Sims DW, Queiroz N, Hobson VJ, Kubicek L, Houghton JDR (2010) The biology and ecology of the ocean sunfish Mola mola: A review of current knowledge and future research perspectives. Rev Fish Biol Fish 20:471-487.

Popp BN, Graham BS, Olson RJ, Hannides CCS, Lott MJ, López-Ibarra GA, Galván-Magaña F, Fry B (2007) Insight into the Trophic Ecology of Yellowfin Tuna, Thunnus albacares, from Compound-Specific Nitrogen Isotope Analysis of Proteinaceous Amino Acids. Stable Isot as Indic Ecol Chang 1:172-190.

Post DM (2002) Using stable isotopes to estimate trophic position: models, methos, and assumptions. . Ecology 83:703-718.

Potter IF, Howell WH (2011) Vertical movement and behavior of the ocean sunfish, Mola mola, in the northwest Atlantic. J Exp Mar Bio Ecol 396:138-146.

R Development Core Team (2008) R Development Core Team.

Riaux-Gobin C, Vetion G, Neveux J, Duchene J-C (1998) Microphytobenthos et 
phytoplancton en baie de Banyuls (golfe du Lion): biomasses pigmentaires et facteurs hydroclimatiques. Vie Milieu 48:1-13.

Riera P, Richard P, Gremare A, Blanchard G (1996) Food source of intertidal nematodes in the Bay of Marennes- Oleron (France), as determined by dual stable isotope analysis. Mar Ecol Prog Ser 142:303-309.

Roach J (2003) World's Heaviest Bony Fish Discovered? Natl Geogr News.

Sawai E, Yamanoue Y, Nyegaard M, Sakai Y (2017) Redescription of the bump-head sunfish Mola alexandrini (Ranzani 1839), senior synonym of Mola ramsayi (Giglioli 1883), with designation of a neotype for Mola mola (Linnaeus 1758) (Tetraodontiformes: Molidae). Ichthyol Res 65:142-160.

Shapiro L (no date)Encyclopedia of Life. http://eol.org/pages/213810/details (accessed 7 June 2018)

Silfer JA, Engel MH, Macko SA, Jumeau EJ (1991) Stable carbon isotope analysis of amino acid enantiomers by conventional isotope ratio mass spectrometry and combined gas chromatography/isotope ratio mass spectrometry. Anal Chem 63:370-374.

Silvani L, Gazo M, Aguilar a. (1999) Spanish driftnet fishing and incidental catches in the western Mediterranean. Biol Conserv 90:79-85.

Sousa LL, Xavier R, Costa V, Humphries NE, Trueman C, Rosa R, Sims DW, Queiroz N (2016) DNA barcoding identifies a cosmopolitan diet in the ocean sunfish. Sci Rep 6:28762.

St John Glew K, Trueman CN, Graham LJ, Mcgill RAR (2019) Spatial models of carbon, nitrogen and sulphur stable isotope distributions (isoscapes) across a shelf sea: an INLA approach. Methods Ecol Evol 10:518-531.

Stock BC, Semmens BX (2013) MixSIAR GUI User Manual.

Syväranta J, Harrod C, Kubicek L, Cappanera V, Houghton JDR (2012) Stable isotopes 

challenge the perception of ocean sunfish Mola mola as obligate jellyfish predators. J Fish Biol 80:225-31.

Thys TM, Ryan JP, Dewar H, Perle CR, Lyons K, O'Sullivan J, Farwell C, Howard MJ, Weng KC, Lavaniegos BE, Gaxiola-Castro G, Miranda Bojorquez LE, Hazen EL, Bograd SJ (2015) Ecology of the Ocean Sunfish, Mola mola, in the southern California Current System. J Exp Mar Bio Ecol 471:64-76.

Vanderklift MA, Ponsard S (2003) Sources of variation in consumer-diet $\delta 15 \mathrm{~N}$ enrichment: A meta-analysis. Oecologia 136:169-182.

Vane K, Larsen T, Scholz-Böttcher BM, Kopke B, Ekau W (2018) Ontogenetic resource utilization and migration reconstruction with $\delta 13 C$ values of essential amino acids in the Cynoscion acoupa otolith. Ecol Evol 8:9859-9869.

Votier SC, Bearhop S, Witt MJ, Inger R, Thompson D, Newton J (2010) Individual responses

Wickham H (2009) R package ggplot2: Elegant Graphics for Data Analysis.

Yokoyama H, Ishihi Y (2003) Feeding of the bivalve Theora lubrica on benthic microalgae: Isotopic evidence. Mar Ecol Prog Ser 255:303-309.

Vander Zanden MJ, Rasmussen JB (2001) Variation in delta N-15 and delta C-13 trophic fractionation: Implications for aquatic food web studies. Limnol Oceanogr 46:20612066. 
23 Table 1. Estimated contribution of different putative prey categories to the assimilated diet of Mediterranean ocean sunfish by size class, based 24 on SIAR mixing models using bulk $\delta^{13} \mathrm{C}$ and $\delta^{15} \mathrm{~N}$ values.

\section{$<50 \mathrm{~cm} \mathrm{TL}$}

Prey functional group

Pelagic jellies

Benthic grazers

Benthic scavengers

Sessile filter feeders

\begin{abstract}
Prey proportion (mode) in diet
\end{abstract}

Fisheries discards

95\% Credibility intervals

Prey proportion (mode) in diet

$50>75 \mathrm{~cm} \mathrm{TL}$

$>75 \mathrm{~cm} \mathrm{TL}$

25

\section{5\% Credibility Prey proportion 95\% Credibility} intervals (mode) in diet intervals

\begin{tabular}{ccc}
$0.45-0.46$ & 0.72 & $0.71-0.72$ \\
$0.17-0.23$ & $<0.1$ & $0.023-0.033$ \\
$0.12-0.017$ & $<0.1$ & $0.0086-0.011$ \\
$0.21-0.23$ & $<0.1$ & $0.019-0.028$ \\
$0.012-0.017$ & $<0.1$ & $0.0091-0.012$ \\
\hline
\end{tabular}




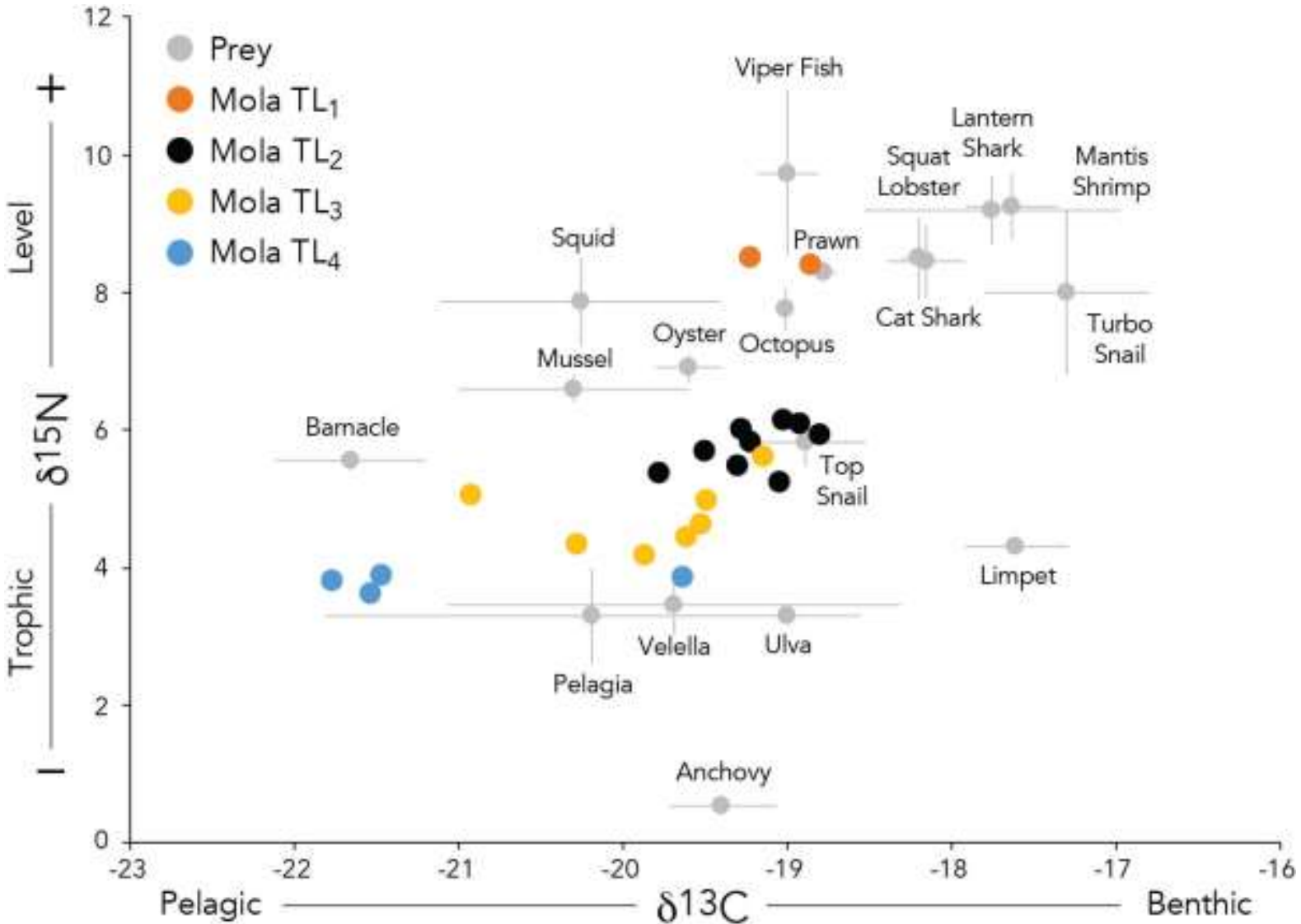

27 Figure 1. Bulk tissue biplot of $\delta{ }^{15} \mathrm{~N}$ and $\delta{ }^{13} \mathrm{C}$ values (\%) for Mediterranean ocean sunfish grouped into size classes ( $\mathrm{TL}_{1}-\mathrm{TL}_{4}$ ) by total length (corrected using TDF's estimated as $2 \pm 1.3$

$29 \%$ for $C$ and $3 \pm 1.2 \%$ for N; McCutchan et al. 2003; Syväranta et al. 2012). Filled points, orange circles: sunfish $20<40 \mathrm{~cm}$ TL, black: sunfish $40<60 \mathrm{~cm}$, yellow: sunfish $60<80 \mathrm{~cm}$, blue: sunfish $80<100 \mathrm{~cm}$. Also shown are mean $( \pm S D$ ) values for local taxa and putative prey (labelled with species common name). 

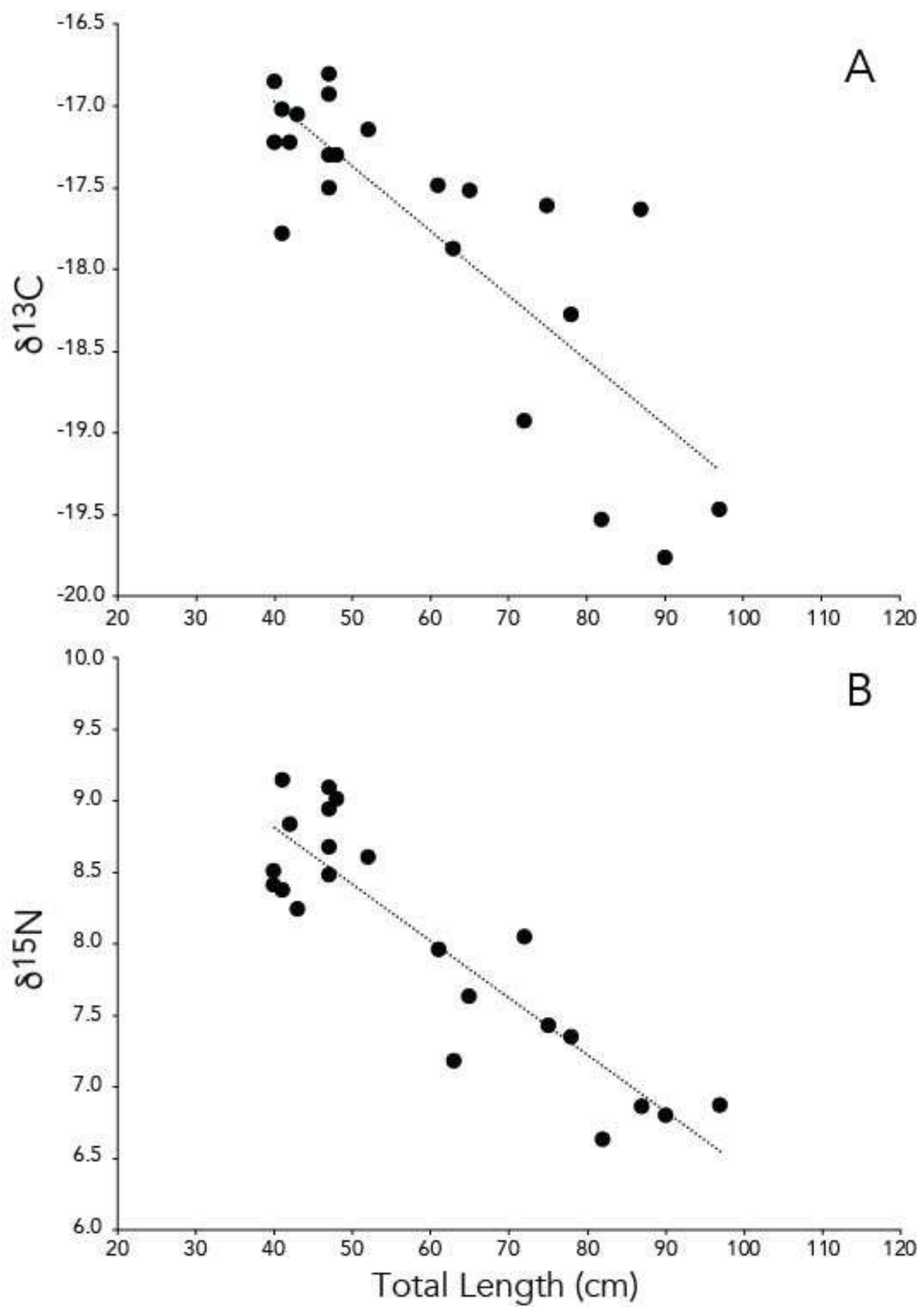

35 Figures 2a and b) Variation in bulk stable isotope values (\%) for Mediterranean sunfish

36 suggests a strong decline in both $\delta^{13} \mathrm{C}\left(\mathrm{A}: \mathrm{R}^{2}=0.67, \mathrm{P}\right.$ value $\left.<0.0001\right)$ and $\delta^{15} \mathrm{~N}$ with size (B:

$37 \quad \mathrm{R}^{2}=0.80, \mathrm{P}$ value $\left.=<0.0001\right)$ 

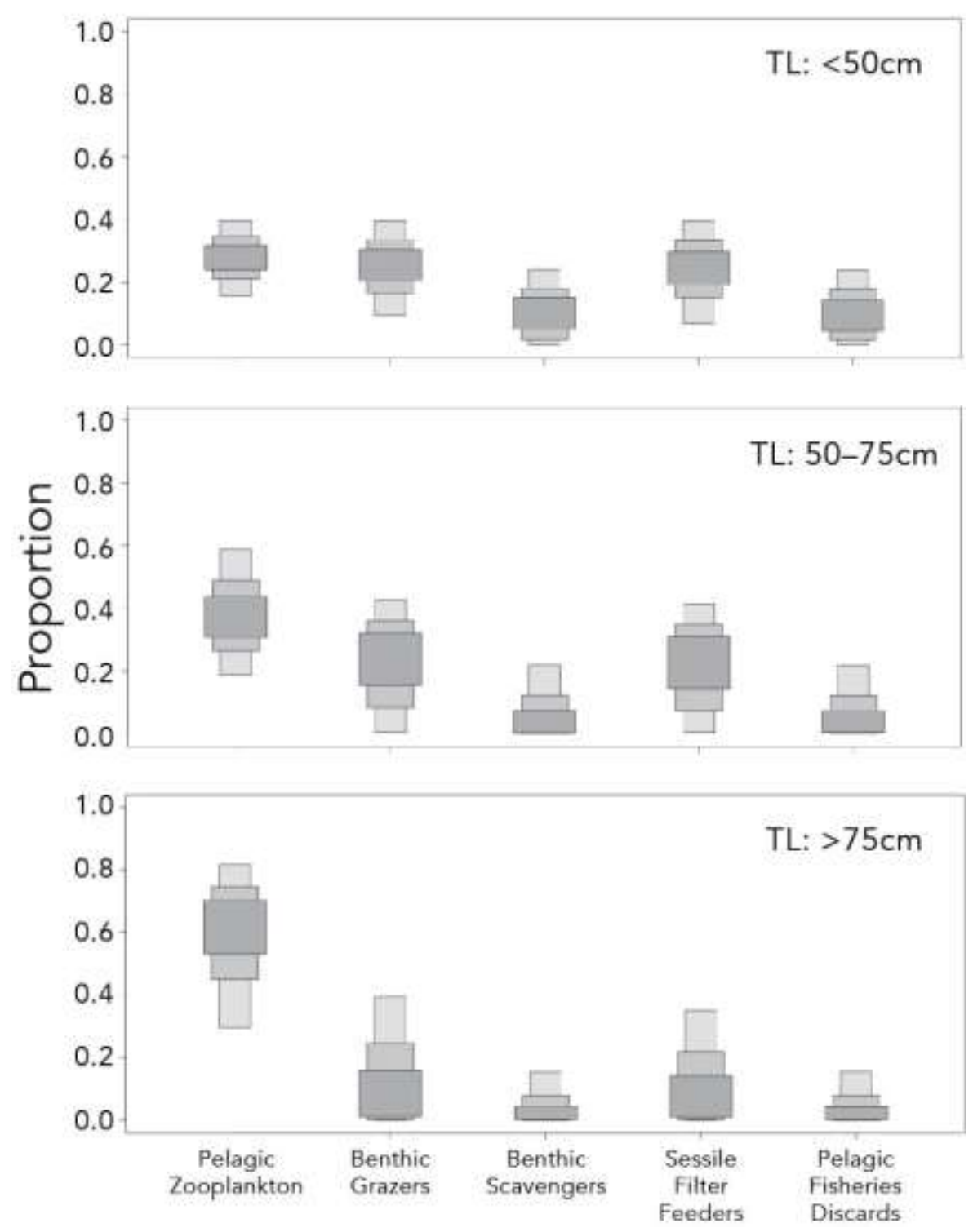

40 Figure 3. Mean estimated proportions of putative prey using SIAR mixing models (grouped $a$

41 priori) in the diet of sunfish; a) $<50 \mathrm{~cm}$, b) $50>75 \mathrm{~cm}$ and c) $>75 \mathrm{~cm}$ TL from the Mediterranean

42 Sea. Putative prey categorised into the following functional groups: Pelagic Zooplankton

43 (represented by Velella velella and Pelagia noctiluca), Benthic Grazers (top snails Gibbula sp.

44 and limpet Patella sp.), Benthic scavengers (mantis shrimp; Squilla sp. and squat lobster:

45 Palinurus sp.), Sessile Filter Feeders (Mytilus sp. and associated saddle oysters; Anomia sp.)

46 and Pelagic Fisheries Discards (cat shark: Galeus sp., lantern shark: Etmopterus sp.). For full

47 data table, see Table 1. 

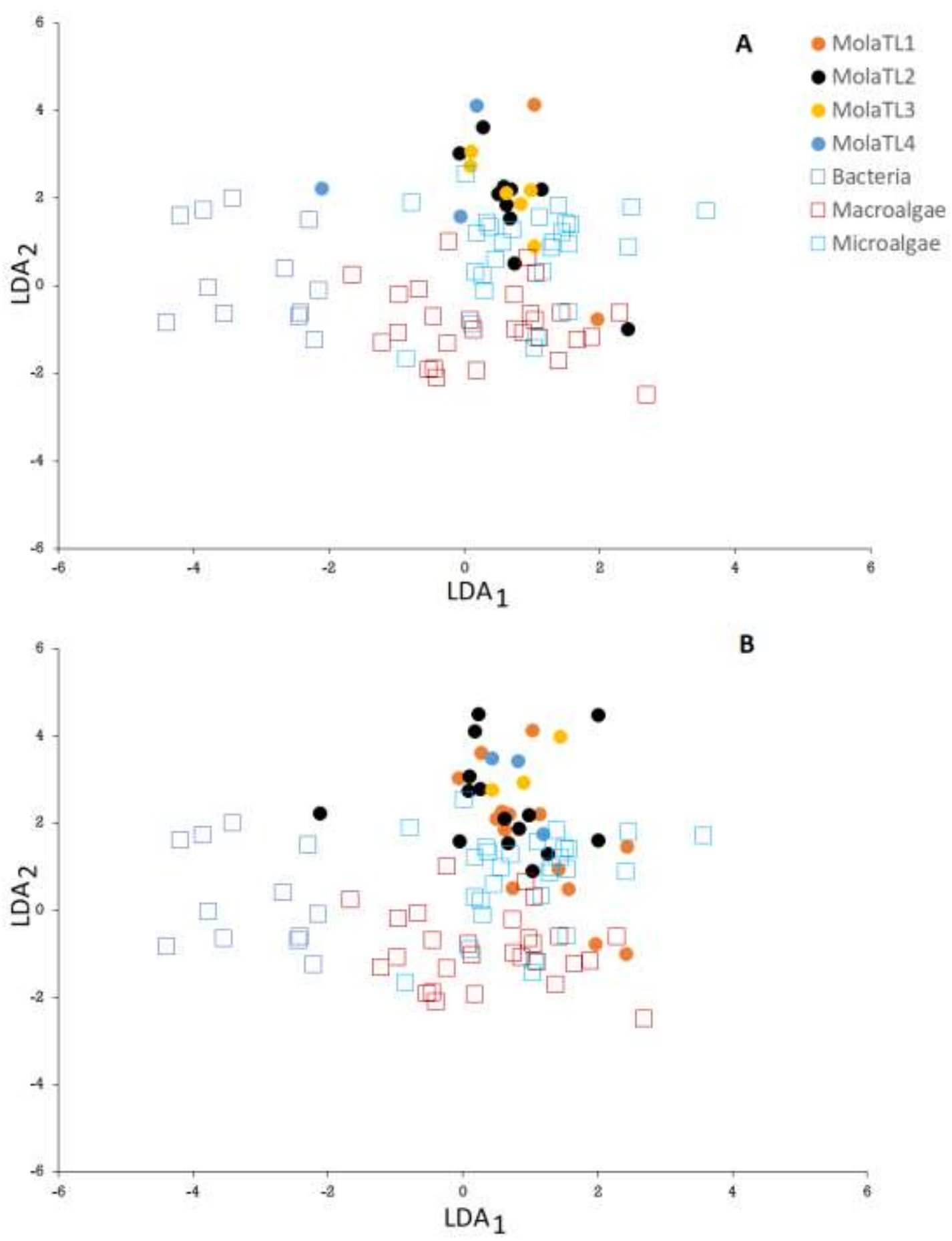

Figure 4. a) Linear discriminatory analysis of Mediterranean sunfish $\mathrm{AA}_{\mathrm{ESS}} \delta^{13} \mathrm{C}$ values

50 alongside fingerprinting datasets of primary producers. Filled points, orange circles: sunfish

$5120<40 \mathrm{~cm}$ TL, black: sunfish $40<60 \mathrm{~cm}$, yellow: sunfish $60<80 \mathrm{~cm}$, blue: sunfish $80<100 \mathrm{~cm}$.

b) Linear discriminatory analysis of global sunfish $A A_{E S S} \delta^{13} C$ values alongside fingerprinting 
$5450<100 \mathrm{~cm}$, yellow: sunfish $100<150 \mathrm{~cm}$, blue: sunfish $150<200 \mathrm{~cm}$, blue: sunfish $<200 \mathrm{~cm}$.

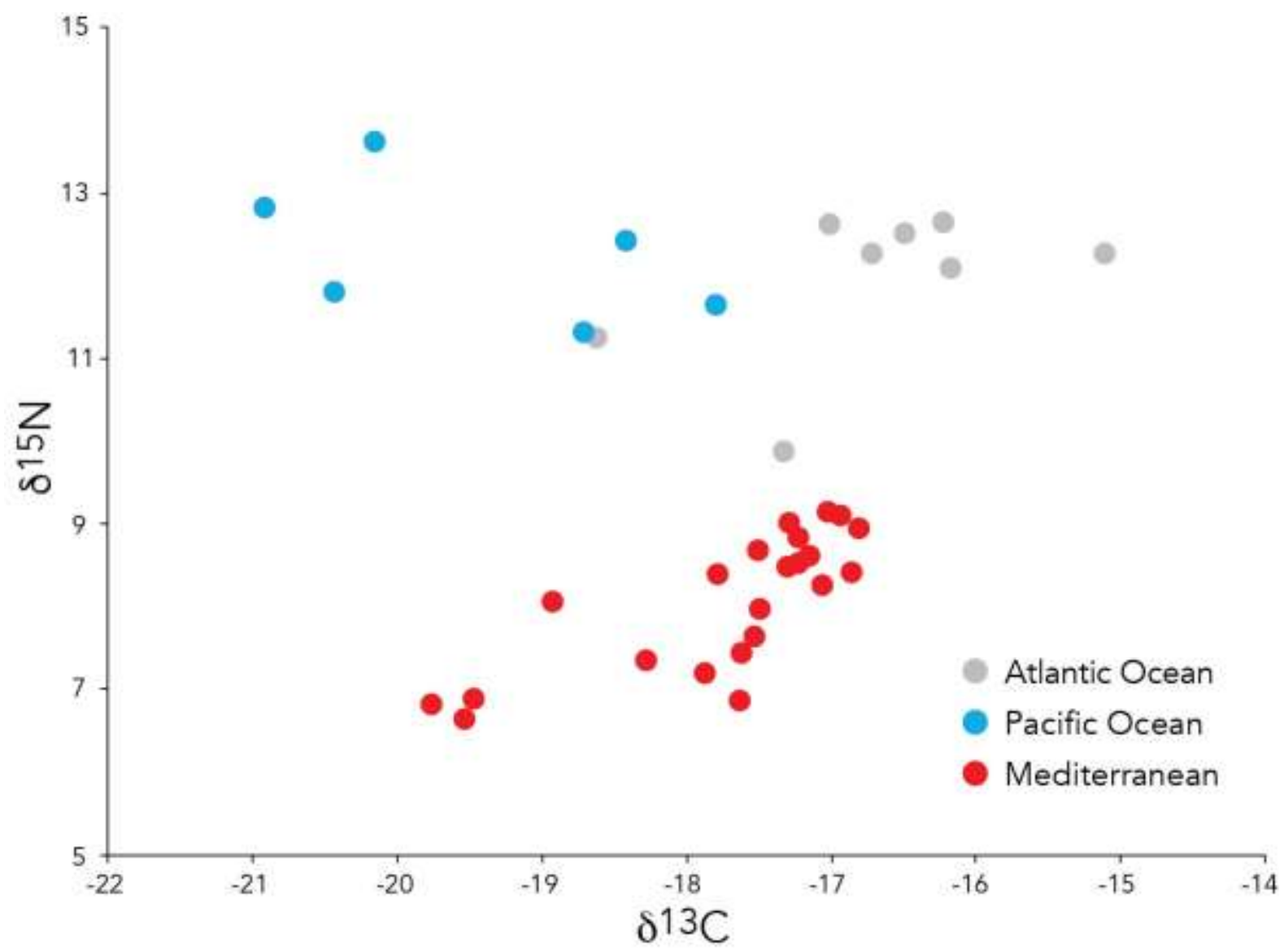

55

56 Figure 5. Ocean sunfish bulk $\delta^{13} \mathrm{C}$ and $\delta^{15} \mathrm{~N}$ values (\%o) for individuals sampled globally. 


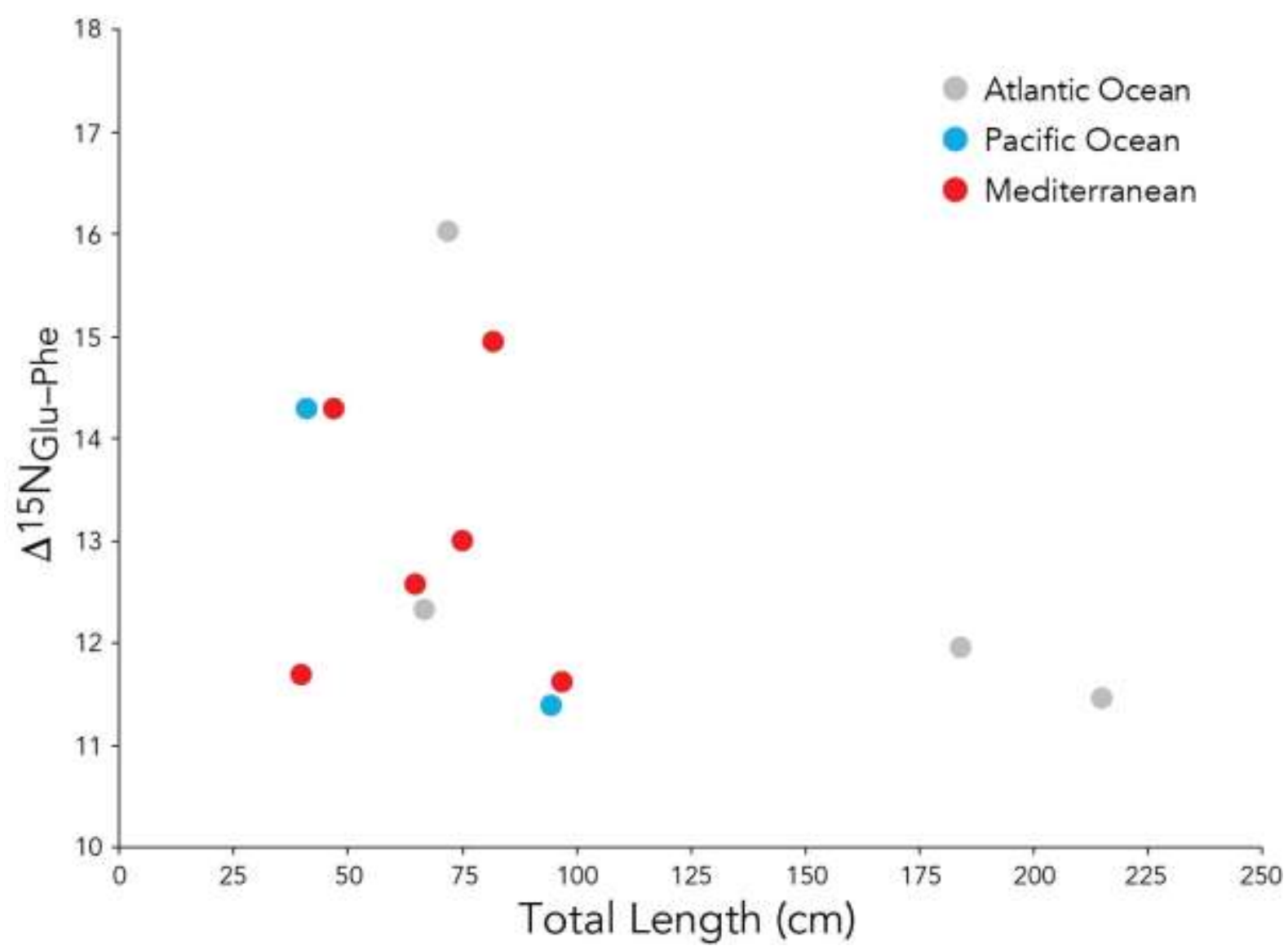

57

58 Figure 6. Relative trophic position of ocean sunfish sampled globally based on amino acid

$59 \quad \delta^{15} \mathrm{~N}\left(\Delta^{15} \mathrm{~N}=\delta^{15} \mathrm{~N}\right.$ glutamic acid - $\delta^{15} \mathrm{~N}$ phenylalanine). For comparison, estimates of $\Delta^{15} \mathrm{~N}_{\mathrm{Glu}}$

60 Phe from other marine taxa have been estimated as $\Delta^{15} \mathrm{~N}_{\mathrm{Glu} \text {-Phe }} \sim 2$ for phytoplankton

61 (equating to trophic position 1 ), $\Delta^{15} \mathrm{~N}_{\text {Glu-Phe }} \sim 12$ zooplankton (trophic position $2<3$ ), $\Delta^{15} \mathrm{~N}_{\text {Glu- }}$

62 Phe $\sim 15$ for marine invertebrates (trophic position $2<4$ ) and $\Delta{ }^{15} \mathrm{~N}_{\text {Glu-Phe }} \sim 20$ for marine fishes

63 (trophic position 3<5) (Nielsen et al. 2015). 